\title{
ВОЗРАСТНЫЕ ОСОБЕННОСТИ ЮНОШЕСКОГО ПЕРИОДА
}

\author{
Абдиева Газиза Ильясовна \\ Международный университет туризма и гостеприимства.
} M.n.H., cm.npen.

\section{SOME AGE FEATURES OF THE YOUTH PERIOD}

\author{
Abdieva Gaziza Ilyasovna \\ M. P. N., st.Rev. \\ International University of Tourism and Hospitality.
}

\begin{abstract}
Аннотация. На основе психологической характеристики попытались дать авторское определение понятия юношеский возраст: юношеский возраст - это период ориентированы на профессиональное становление личности как основного психического новообразования, проявляющегося в учебно-воспитательном процессе образовательного пространства.

Annotation. On the basis of the psychological characteristics, we tried to give the author's definition of the concept of youth: youth is a period focused on the professional development of the individual as the main mental neoplasm that manifests itself in the educational process of the educational space.

Ключевые слова: личность в юношеском возрасте, возрастные особенности, возрастной период юношества, юношеский возраст, психические новообразования.
\end{abstract}

Keywords: personality in adolescence, age-specific features, youth age period, early life, mental neoplasms.

Возрастные особенности человека впервые изучено древнегреческим философом Аристотелем. Периоды развития человека от рождения до юношества, он рассмотрел как период, когда каждый человек обязательно усваивает определенные социальные нормы, правила, ценности и приспосабливается к социуму. Такие идеи древнегреческого философа Аристотеля способствовали дальнейшему применению понятий «юношество» в психологической науке.

Понятие возраст - одно из базовых категории для возрастной психологии. Возраст как категория возрастной психологии впервые последовательно представлено в деятельностном подходе А.Н. Леонтьева. По его утверждению, возраст - «изменение места, занимаемого человеком в системе общественных отношений, который может ответить на вопрос о движущих силах развития его психики» [1, с. 67].

В науке представлена не только хронологическая (количество прожитых лет) возрастная категория человека, но и физический возраст, биологический возраст, психологический возраст и социальный возраст развития человека. Так, И.С. Кон отмечал, что биологический возраст фиксирует этапы развития организма и определяется соответствующими семантическими признаками, психологический возраст отражает конкретные стадии психического развития индивида, а социальный возраст показывает, какое место в данном обществе занимает данная возрастная группа.

В совокупности возраст - есть единство влияния на человека роста, физиологического и нервнопсихологического созревания в условиях его жизнедеятельности и воспитания, т. е. по И.С.Конту возраст индивида представляет собой количество лет в совокупности с духовным развитием личности [2, с.103-104]. Соотношение биологического и социального в разные периоды жизни человека проявляются неодинаково, это и есть установление границ юношества как определенной продуктивной возрастной категории человека. Смена возрастных периодов из одного возраста в другой сопровождается показателями количественных и качественных изменении в жизни человека. В своей культурно-исторической теории Л.С.Выготский указывал, что возраст представляет собой целостное динамическое образование, такую структуру, которая определяет роль и удельный вес каждой частичной линии развития. Возраст есть не что иное, как известный цикл развития, как бы замкнутый в себе, отграниченный от других циклов, который отличается своими своеобразными темпами и своим своеобразным содержанием развития. Для установления этапов психического развития человека, Л.С. Выготский $[3$, c. 80$]$,

В психологической науке периодизация основана на выделении возрастных особенностей человека. Возраст является одной из важных характеристик юношества. Психология юношеского возраста, как один из разделов возрастной психологии. В XVIII веке Ж.-Ж. Руссо была заложена теоретическая основа концепции юношеского возраста. И с этого периода Ж.-Ж. Руссо были выделены следующие возрастные периоды: 16-17 лет - ранняя юность; 17-20 лет - собственно юность; 20-21 год - поздняя юность.

Западные ученые (Д.Векслер, Д. Биррен, Д.Бромель), занимавшиеся проблемой возрастной психологии, выделили следующие классификации: юность - от 16 до 21 года, ранняя зрелость - от 21 до 25 лет (Д.Векслер); юность - от 11 до 21 года, ранняя зрелость от 21 до 25 лет (Д.Бромель) [4, с.61]. В западной психологии вообще 
преобладает традиция общего объединения подросткового возраста и юности в единый возрастной период, называемый периодом взросления (англ.adolescence; на рус. языке этот термин определяется как «юность») [5, c.214].

Возрастные границы юношества (17 лет - 21 год) устанавливаются, исходя из стадий физиологического развития и полового созревания (акселерация) человека. Энциклопедическое определение понятия «юноша» определяется как «молодой», «малый», «парень от 15 до 21 лет и более». Юношеский возраст (англ. juvenile age ) - период жизни человека между подростковым возрастом и взрослостью. Принятой специалистами по проблемам возрастной морфологии, физиологии и биохимии юношеский возраст был определен как 17- 21 г. для юношей и 16-20 лет - для девушек [6, с.559].

В психологической науке И.С Кон, разработал известную теорию перехода от детства к взрослости и разделил их на основные три этапа: подростковый, юношеский, поздняя юность. Именно «переходной возраст» как стадия перехода от детства к зрелости имеет свою биологическую основу как половое созревание, поэтому его называют пубертантным периодом в психологической науке. Этот период предполагает не только физическое созревание, но также приобщение к культуре, овладение определенной системой знаний, норм и навыков, благодаря которым индивид может трудиться, выполнять общественные функции и нести вытекающую социальную ответственность. Как отмечает, И.С.Кон, «периодизация жизненного пути всегда включает нормативно-ценностный момент, указание на то, какие задачи должен решать индивид, достигший данного возраста, чтобы своевременно и успешно перейти в следующую жизнь и возрастную категорию» [7, с.8]. Именно юношеский возраст, характеризуется зарождением значимых новообразований, детерминирующих развитие значимых личностных

структур

[8, c. 129].

Л.С. Выготский, для установления этапов психического развития человека, [9, с. 80], выделяет основные психологические признаки возрастных периодов на основе следующих трех параметров: социальная ситуация, которая приводит к формированию психических новообразовании как продукта возрастного развития, ведущие виды деятельности, необходимые для психического развития человека и социальное общение. Именно социальная ситуация как одна из основных психологических характеристик юношеского возраста рассматривает самостоятельный выход в профессиональную деятельность, который определяет дальнейшее место и социальный статус человека в обществе.

Именно, одним из важных, составляющую психологическую основу одного из психических новообразовании личности является профессиональное самоопределение в юношеском возрасте, который составляет осознание человека в качестве взрослого представителя социума, личностная потребность осознания социального места и признание его как профессионала. Поэтому самым важным делом для юношества становится выбор профессии, который систематизирует его мотивационные тенденции в юношеском возрасте, исходящие от личностных интересов и мотивов, порождаемых условиями профессионального выбора.

Возрастной период юношества является для человека особо важным этапом перехода от детства к юношеству - он вступает во взрослую, и в самостоятельную жизнь. Юношеский период развития есть самое начало самостоятельной и взрослой жизни человека. Поэтапность перехода от детства к самостоятельности предполагает завершение физического созревания, достижение социальной зрелости и период завершения первичной социализации человека в обществе. Б.Г.Ананьев, в юношеском возрасте, выделил две основные фазы. Фазу ранней юности отличающей неопределенностью положения человека в обществе. В этом возрасте юноша осознает, что уже не ребенок, но вместе с тем еще и не взрослый. Юность по определению, Б.Г.Ананьева, как таковая, представляет собой начальное звено зрелости. По его утверждению, юношеский возраст является сензитивным периодом для развития основного социогенного потенциала человека. Одним из главных мотивов проявления такого потенциала является познавательно-психический процесс в продуктивной деятельности юношеского возраста. Профессиональное становление есть характерная черта юношеского возраста в процессе социализации. Период жизни человека от 17 до 25 лет, считает Б. Г. Ананьев, имеет важное значение как завершающий этап формирования личности на стадия профессионализации. К 17 годам у личности создаются оптимальные субъективные условия для формирования навыков самообразовательной деятельности [10, с.53].

Стремление личности приобрести социально-значимую профессию усиливает творческие способности, развивает интеллектуальные и физические возможности в юношеском возрасте. Становление юношеского интеллекта выражается в обобщении, поиске закономерностей развития и принципов познания как одного из основ новообразовании проявляющейся в юношеском возрасте. Изучение закономерностей развития человека в юношеском возрасте как периоде интенсивного интеллектуального развития, профессионального становления, усвоения социальных ролей, вхождения в новую «взрослую» жизнь позволяет говорить об особенностях юношеского возраста в процессе социализации личности. Это период количественного и качественного развития человека, который относится к началу самостоятельной и взрослой жизни как ответственный период личностнопрофессионального развития.

Личность в юношеском возрасте выбрав профессию, ориентирован на социальный статус, на формирование своего мировоззрения и самосознания как основного психологического новообразования юношеского возраста. 
Психические новообразования в юношеском возрасте имеют возрастную психофилогенетическую основу, которая проявляется как объективный показатель количественного и качественного изменении. Основными психические новообразования юношеского возраста являются: становление и развитие самосознания, развитое осознание личностного «Я», активное формирование мировоззрения, жизненных планов; установка на построение личной жизни, глубокая рефлексия и самоопределение в выборе профессии, развитие идентичности, вхождение в социум. В процессе профессионального становления в вузе нарастает тенденция к индивидуализации во всех основных компонентах профессиональной направленности, которые закладывают личностнопрофессиональные качества, необходимые будущему специалисту. При рассмотрении вопроса возрастных особенностей юношеского периода, психологические новообразования приводят к успешному профессиональному становлению будущего специалиста.

Возрастные особенности юношеского периода характеризуется:

1) С биологической, где проявляются врожденные качества человека как индивида: телосложение, черты лица, цвет кожи, разрез глаз, рост, тип высшей нервной деятельности, строение анализаторов, рефлексы, инстинкты, физическая выносливость организма, и которые под влиянием внешних факторов видоизменяются.

2) С психологической - это психические свойства человека с учетом индивидуальных особенностей личности, от которых зависит общее протекание всех психических процессов и возникновение психических состояний человека в юношеском возрасте как особый период психических новообразований.

3) С социальной - личность в юношеском возрасте является представителем определенной социальной группы, который активно включается в социальные отношения и активно усваивает социальные роли в процессе взаимодействия в обществе.

На основе психологической характеристики попытались дать авторское определение понятия юношеский возраст: юношеский возраст - это период ориентированы на профессиональное становление личности как основного психического новообразования, проявляющегося в учебно-воспитательном процессе образовательного пространства.

\section{Список литературы}

1. Леонтьев А.Н. Проблемы развития психики. - М., - 1972. - с. 67

2. Кон И.С. Социология личности. - М., -1967. - с.103-104

3. Выготский Л.С. (Антология гуманной педагогики). - Переиздание. М: Издательский Дом Ш. Амонашвили, - 2002. - с. 80

4. Павловский В.В. Ювенология. -М., -2001. - с.61

5. Мещеряков Б., Зинченко В. Большой психологический словарь.- М., -2003. - с.214

6. Даль В.. Толковый словарь живого великорусского языка. В 4-х томах. - М., -1998. - с.559

7. Кон И.С. Психология юношеского возраста. -М., -1977. - с.8

8. Малютина Т.В. Психологические и психофизиологические особенности развития в юношеском (студенческом) возрасте. //Омский научный вестник. - Омск, - 2013. - с. 129

9. Выготский Л.С. (Антология гуманной педагогики). - Переиздание. М: Издательский Дом Ш. Амонашвили, - 2002. - с. 80

10.Ананьев Б.Г. К психофизиологии студенческого возраста. //Современные психические проблемы высшей школы. - Л., - 1974. - с.53 